\title{
XII. Singular instance of the attachment of birds of prey to their young
}

\section{Cronstedt}

To cite this article: M. Cronstedt (1799) XII. Singular instance of the attachment of birds of prey to their young , Philosophical Magazine Series 1, 3:10, 176-177, DOI: 10.1080/14786449908676979

To link to this article: http://dx.doi.org/10.1080/14786449908676979

曲 Published online: 18 May 2009.

Submit your article to this journal $\sqsubset \pi$

Џ Article views: 2

Q View related articles $\square$ 


\section{$\left[\begin{array}{lll}176 & ]\end{array}\right.$}

XII. Singular Inftance of the Attachment of Birds of Prey to their Young. By M. CRONSTEDT. From New Tranfactions of the Royal Academy of Sciences at Stockholm, Vol. $X$.

Mr. Cronftedt refided feveral years on a farm in Sudermania, near a ffeep mountain, on the fummit of which two eagle-owls (ftrix bubo L) had their neft. One day, in the month of July, one of the young owls having quitted the neft was caught by fome of his fervants. This bird, confidering the feafon of the year, was well feathered; but the down appeared here and there between thofe feathers which had not yet attained their full growth. After it was caught, it was fhut up in a large hen-coop, and next morning M. Cronftedt found a young partridge lying dead before the door of the coop. $\mathrm{He}$ immediately concluded that this provifion had been brought thither by the old owls, which no doubt had been making fearch in the night-time for the loft young one, and might have been led to the place of its confinement by its cry. This turned out to have been actually the cafe; for $M$. Cronftedt found that the fame mark of attention was repeated every night for fourteen days. The game which the old ones carried to it confifted chiefly of young partridges, for the moft part newly killed, but fometimes a little fpoiled. One time a moor-fowl was brought to the young owl, fo freth that it was ftill warm under the wings: a putrid ftinking lamb was alfo brought. M. Cronftedt fuppofes that the fpoiled fleth had already lain a long time in the neft of the old owls, and that they brought it merely becaufe they had no better provifion at the time. He and his fervant tried to watch feveral nights, in order that they might obferve through a window when this fupply was depofited ; but their plan did not fucceed, and it would appear that thefe owls, which are very fharp-fighted, had difcovered the moment when the window was not watched, as food was found to have been depofited for the young before 
the coop that very night. In the month of Auguft this care ceafed; but that period is exactly the time when all birds of prey abandon their young to their own exertions. It may be readily concluded, from this inftance, how much game mut be deftroyed by a pair of thefe owls during the time that they rear their young. This obfervation is applicable to the whole race of owls, in general; and thefe may be confidered therefore as the moft deftructive of all the birds of prey. As the eatable-birds of the foreft repair chiefly in the night-time to the fields, they are particularly expofed to the acute fight, fmell, and claws of theie birds of the night; and even the fwift-footed hare feldom efcapes them.

XIII. A ghort View of the Mitchillian Theory of Fever, and of Contagious Difeafes in general.

Tis ERTAIN exhalations from marnes and fwamps, and from collections of putrefying vegetable and animal fubftances, induce difeafes attended with different degrees of malignity, according to circumftances. There is a great fimilarity at leaft in the difeafes induced by the exhalations from marthes and from putrefying fubftances: it ought to be fo; for the noxious quality of the former is in confequence of their containing the latter; and hence fuch difeafes, though improperly, have been called putrid.

What is the peculiar fubftance, or what the fubftances in thefe exhalations that caufe what are termed contagious difeafes? What the mode of action? Animal and many vegetable fubftances, efpecially thofe which contain gluten, give fimilar products when decompofed by the putrefactive procefs.

Can hydrogen gas be the deleterious product? No-its bafe combined with different fubftances makes a great part of our aliment: with carbon it forms fat-with oxygen, Vox. III. 